\title{
Evaluation of antibiotics dispensing profile in Tubarão, Santa Catarina, Brazil
}

\author{
Claudia Rauber, Micheli Regina Feltrin, Anna Paula Piovezan
}

Pharmacy Undergraduate Program, Clinical Analysis Specialty, University of Southern Santa Catarina

\begin{abstract}
Antibiotics are drugs widely used in prophylaxis and treatment of a great number of diseases. However, their use must be carefully controlled as acquisition in pharmacies, often without medical prescription, is elevated. The role of pharmacists in these circumstances is to practice dispensation in a rational manner. Through a structured questionnaire with open and closed questions, this study investigated the profile of antibiotics dispensed in pharmacies of Tubarão, Santa Catarina, Brazil. From the responses, it was observed that $85.0 \%$ dispense this class of medicine without medical prescription, mainly for treatment of respiratory (62.8\%) and urinary (12.0\%) tract disorders. Moreover, pharmacists' guidance was largely focused on posology $(66.6 \%)$ and drug interaction $(12.6 \%)$, in addition to the interactions with contraceptives, alcohol and milk. The importance of avoiding antibiotics dispensation without medical prescription must be emphasized, as well as the benefits of educating the population to promote the rational use of medicines.
\end{abstract}

Uniterms: Pharmacy/medicines control. Antibiotics/dispensation profile. Antibiotics/rational use.

Antibióticos são fármacos amplamente utilizados na profilaxia e no tratamento de grande número de doenças. Entretanto, seu uso deve ser cuidadosamente controlado nas farmácias, uma vez que nestas a aquisição sem prescrição médica é elevada. O papel dos farmacêuticos nessas circunstâncias é o de praticar a dispensação de maneira racional. Por meio de questionário estruturado, com questões abertas e fechadas, investigou-se o perfil dos antibióticos dispensados em farmácias de Tubarão, Santa Catarina, Brasil. Pelas respostas, observou-se que $85 \%$ das dispensa essa classe de medicamentos sem prescrição médica, principalmente para o tratamento de problemas dos tratos respiratório $(62,8 \%)$ e urinário $(12,0 \%)$. Além disso, a orientação dos farmacêuticos se focou amplamente na posologia $(66,6 \%)$ e nas interações com fármacos (12,6\%), em adição às interações com anticoncepcionais, álcool e leite. A importância de se proibir a dispensação sem prescrição médica deve ser enfatizada, assim como os benefícios da educação da população para promover o uso racional de medicamentos.

Unitermos: Farmácia/controle de medicamentos. Antibióticos/perfil de dispensação. Medicamentos/ uso racional.

\section{INTRODUCTION}

The development of antimicrobial drugs (antibiotics) has led to a reduction in morbidity and mortality of many infectious diseases. However, indiscriminate use is causing other health issues, such as resistance of microorganisms to the drugs and a decrease in effectiveness (Howard et al., 2003). In a bid to prevent this scenario, official documents (WHO, 2001) and scientific studies (Nascimento-Carvalho, 2006) stress the importance of

*Correspondence: A. P. Piovezan. Curso de Farmácia, Universidade do Sul de Santa Catarina - UNISUL, Av. José Acácio Moreira, 787 - Bairro DEHON, 89.704-900 - Tubarão - SC, Brasil. E-mail: anna.piovezan@unisul.br rational antibiotic use, driven mainly by the appropriate choice of pharmacological agent through laboratory clinical diagnosis of etiologic agent sensitivity, and identification of infectious agents by qualified and skilled professionals (Oliveira et al., 2004).

The nature of the pharmaceutical profession, and the different realities of the locations where these professionals work, presents challenging situations regarding the rational use of medicines. The population's difficulty of access to the health system is one example which is conducive to self-medication. The large number of advertisements encouraging the consumption of medicines is also a significant factor (Luchessi et al., 2005). 
With regard to this issue, however, and more importantly in the case of antibiotics, pharmacists should bear in mind that the official recommendation concerning their role is to identify mild or moderate diseases, whose symptoms are self-limited and for which they can dispense medicines that do not require medical prescription, while advising the patient to consult a doctor if symptoms persist beyond a few days (WHO, 2004).

The aim of this study was to evaluate the antibiotics dispensation profile in Tubarão, Santa Catarina, Brazil, considering the request for these drugs without medical prescription or pharmacist guidance.

\section{MATERIAL AND METHODS}

\section{Population and Sample}

Pharmacists responsible for the pharmaceutical establishments in Tubarão, Santa Catarina were the object of this research. As inclusion criterion, only pharmacists who dispense drugs, duly registered in the Regional Pharmacy Council of the State of Santa Catarina, who were present in the pharmacy at the time of the visit, and who consented to participate in the study, were interviewed. Those working at prescription pharmacies, those who were not present at the time of visit, and subjects who refused to participate in the interview were excluded.

Of the 90 pharmacies in Tubarão included in the Regional Pharmacy Council; during the study period, three were excluded because they were exclusively prescription pharmacies, six because they were no longer in operation, nine were rejected because the pharmacist in charge refused to participate in the study, and twenty-six were not included because their pharmacists were not present at the time of the visit. The final sample therefore consisted of 46 interviewees.

\section{Type of study}

The research was conducted through an exploratory, descriptive, and crosssectional field study.

\section{Procedure}

On the days of the interviews, the undergraduates visited the pharmacists and invited them to participate in the study, presenting and explaining the research objectives. Those who agreed to participate in the study signed a Term of Free and Informed Consent and completed a standard questionnaire (the assessment tool), according to the protocol approved by the Research Ethics Committee of UNISUL under number 07.091.4.03.III.

\section{Assessment tool}

The questionnaire was composed of both closed and open-ended questions. The first few questions were intended to characterize the pharmaceutical establishment and consisted of closed questions about the "kind of establishment" with the answer options: dispensing or prescription; and if yes, a question on whether the pharmacist was the owner, with the answer options of yes or no.

To identify the demand for different classes of antibiotics by the municipality's population, various questions with open and closed answers were asked. These questions were intended to investigate: a) the number of persons seeking this class of medicines with or without medical prescription, in either the summer or winter, with the following response options: 1 to 5 per week, up to 10 per week, or more than 10 per week; b) the demand for this class of drugs without medical prescription for use in children, adults, the elderly, or pregnant women, for the treatment of recurrent symptoms, and for symptoms not related to the infection; and c) the users' most common questions regarding this class of medicines.

Another series of questions sought to identify aspects of the guidance provided by pharmacists to the population at the time of antibiotics dispensation. These included a question containing only alternatives for closed answers, such as, how long had it been since the pharmacist in charge graduated. The response options were: up to 5 years, between 5 and 10 years, more than 10 years.

Some additional guidance-related questions were asked with open answer options including: a) "Do you encourage the sale of this class of medicines in the following morbidities: , or when the person's symptoms show a clear need, such as:__ ? Finally, the following open-ended questions were asked: a) "What criteria do you use to select antibiotics in the case of dispensing without medical prescription?"," b) "Which drug interactions of antibiotics do you usually point out to patients?" c) "Which information do you emphasize most when dispensing antibiotics?"," d) "What do think about having participated in this research?"," and e) "Would you like to make any further comments on this research?"

\section{Data analysis}

Student's t-test was used to analyze the responses comparing the guidelines provided by pharmacists when dispensing antibiotics without medical prescription. Other results were evaluated by descriptive analysis, taking into account the proportion of responses for all answers to 
each question, where the results were presented as relative frequency.

In order to analyze the criteria for selecting and dispensing antibiotics without medical prescription, responses were compared against the guidelines in the Consensus Document on the Use of Antibiotics in Primary Health Care (Documento de Consenso Sobre la Utilización de Antibióticos en Atención Primaria - AEPap, 2006). With regard to answers about possible drug interactions of this class of medicines, Drugs Interaction Facts (Tatro, 2003) was consulted.

\section{RESULTS}

The first section of the research questionnaire on pharmaceutical establishments in Tubarão, Santa Catarina, found that only $3.3 \%$ were dispensing pharmacies, and that $39.0 \%$ of the establishments were owned by pharmacists.

Interviewees' responses to questions seeking to characterize the demand profile for antibiotic drugs in the municipality can be summarized as follows: when patients seek antibiotics without medical prescription, in most cases they want them for use in adults $(64.0 \%)$, but sometimes in children $(27.8 \%)$, the elderly $(3.3 \%)$, and pregnant women $(1.6 \%)$. Concerning a possible seasonal variation in the demand for these drugs, responses indicated that the number of individuals seeking antibiotics in the selected area during Summer was 1 to 5 people per week $(56.0 \%)$, increasing to more than 10 per week during winter $(54.0 \%)$.

For questions that aimed to characterize the dispensation profile of this class of medicine in the studied area, it was observed that, while $15.0 \%$ of respondents replied that antibiotics dispensation only occurred under medical prescription, a relatively large number of pharmacists (85.0\%) said they dispensed them without prescription. As shown in Table I, Panel A, among the main diseases for which the pharmacists said they oversaw sales of antibiotics without medical prescription were throat infection $(29.0 \%)$, urinary tract infection $(12.0 \%)$, ear infection (11.0\%), and sinusitis (8.4\%). In Table I, Panel B, the responses indicate that the respondents' main symptoms indicating antibiotics were: high fever $(23.6 \%)$, formation of throat plaques $(16.2 \%)$, presence of pus $(7.5 \%)$ and sore throat (6.4\%), among others. In addition, among the criteria for the selection of antibiotics to be dispensed, pharmacists responded according to the document used for comparison in this study, such as situations of possible drug allergy (15.1\%), association with the severity of pathology $(15.1 \%)$, and the purpose of the antibiotic (11.3\%), among others (Table II). However, $44.6 \%$ of the interviewees had responses that are not specified in the reference document.

When the interviewees were asked about the guidance that they emphasize upon dispensing (Figure 1 , panel B), they responded that they offered guidance in particular on posology $(66.6 \%)$, drug interactions

TABLE I - Pharmacists' recommended sales of antibiotics in Tubarão, Santa Catarina. Major morbidity described by pharmacists, but not diagnosed (A), and symptoms (B) for which sale occurs without medical prescription

\begin{tabular}{lc}
\hline A) Types of morbidity & Percentage of answers \\
\hline Throat infection & 29.0 \\
Urinary infection & 12.0 \\
Ear infection & 11.0 \\
Sinusitis & 8.4 \\
Pharyngitis & 6.0 \\
Upper airway infection & 6.0 \\
Pneumonia & 2.4 \\
Fever & 2.4 \\
Dental infection & 2.4 \\
Throat plaque & 2.4 \\
Clear and simple infection & 2.4 \\
Skin infection & 1.2 \\
Intestinal infection & 1.2 \\
Cough with secretion & 1.2 \\
Oral infection & 1.2 \\
Acne & 1.2 \\
\hline B) Types of symptoms & Percentage of answers \\
\hline High fever & 23.6 \\
Plaque formation & 16.2 \\
Pus & 7.5 \\
Pain & 7.5 \\
Sore throat & 6.4 \\
Sinusitis & 5.4 \\
Headache & 4.3 \\
Edema & 3.2 \\
Non-effective anti-inflammatory & 3.2 \\
Intense redness & 2.1 \\
Severe cramps & 1.1 \\
Diarrhea & 1.1 \\
Inflammation & 1.1 \\
Symptoms for more than seven days & 1.1 \\
Mucus & 1.1 \\
Did not answer & 15 \\
\hline
\end{tabular}


TABLE II - Selection profile for the dispensation of antibiotics without medical prescription in Tubarão, Santa Catarina. Comparison with criteria to be considered prior to treatment with antibiotics, according to the Consensus Document on the Use of Antibiotics in Primary Health Care (Documento de Consenso Sobre la Utilización de Antibióticos en Atención Primaria - AEPap, 2006)

\begin{tabular}{|c|c|c|}
\hline $\begin{array}{l}\text { In accordance with } \\
\text { the literature }\end{array}$ & Criteria & Percentage of answers \\
\hline yes & If the patient is allergic to the medicine & 15.1 \\
\hline yes & If associated with the severity of symptoms and pathology & 15.1 \\
\hline yes & Purpose of the antibiotics & 11.3 \\
\hline yes & If there is presence of plaques & 2.8 \\
\hline yes & Duration of treatment & 1.8 \\
\hline yes & Patient clinical history & 1.8 \\
\hline yes & Which medicine is safer for the patient & 1.0 \\
\hline yes & Patient weight & 1.0 \\
\hline yes & If there is presence of pus or mucus & 1.0 \\
\hline \multirow[t]{2}{*}{ yes } & Only with medical prescription & 1.8 \\
\hline & Answers in accordance with the document & 52.7 \\
\hline no & If there is fever & 9.4 \\
\hline no & If the patient uses another antibiotic & 8.5 \\
\hline no & Age of patient & 5.6 \\
\hline no & Price of product & 3.7 \\
\hline no & If person is using other medication & 2.8 \\
\hline no & If person has previously sought medical advice & 2.8 \\
\hline no & Ease of adherence to treatment & 1.8 \\
\hline no & If person has used other non-effective antibiotics & 1.0 \\
\hline no & If person has already used an anti-inflammatory & 1.0 \\
\hline no & Body temperature & 1.0 \\
\hline no & How many days with fever & 1.0 \\
\hline no & If the request for antibiotics is recurrent & 1.0 \\
\hline no & Which administration route is used & 1.0 \\
\hline no & If prior medication has been used & 1.0 \\
\hline no & If there are signs of infection & 1.0 \\
\hline no & If the patient has a health plan & 1.0 \\
\hline \multirow[t]{2}{*}{ no } & If there is presence of sore throat & 1.0 \\
\hline & Answers in discordance with the document & 44.6 \\
\hline
\end{tabular}

$(12.6 \%)$ and adverse effects $(7.2 \%)$. Guidelines on the drug's therapeutic action were seldom mentioned (1.0\%). However, when asked about the most frequent doubts that users expressed at the time of purchase (Figure 1, Panel A), the respondents' answers were, in descending order; about posology (46.7\%), possible drug interactions $(28.0 \%)$, therapeutic action $(11.2 \%)$ and adverse effects $(9.0 \%)$.

Regarding the posology of medicines, a statistically significant difference was observed $(\mathrm{P}=0.001)$ between the percentage of respondents who said that this was a frequent doubt of antibiotics users (46.7\%) and those who stated that they offered guidance on this aspect $(66.6 \%)$

The main types of drug interactions for which pharmacists stated guidance was offered to patients were (data not shown) interactions with oral contraceptives (38.1\%), milk (13.1\%) and alcohol (10.7\%). According to the consensus literature (Tatro, 2003), only the last two have some level of clinical relevance, in the coadministration with tetracycline and cephalosporin, respectively (Table III). 

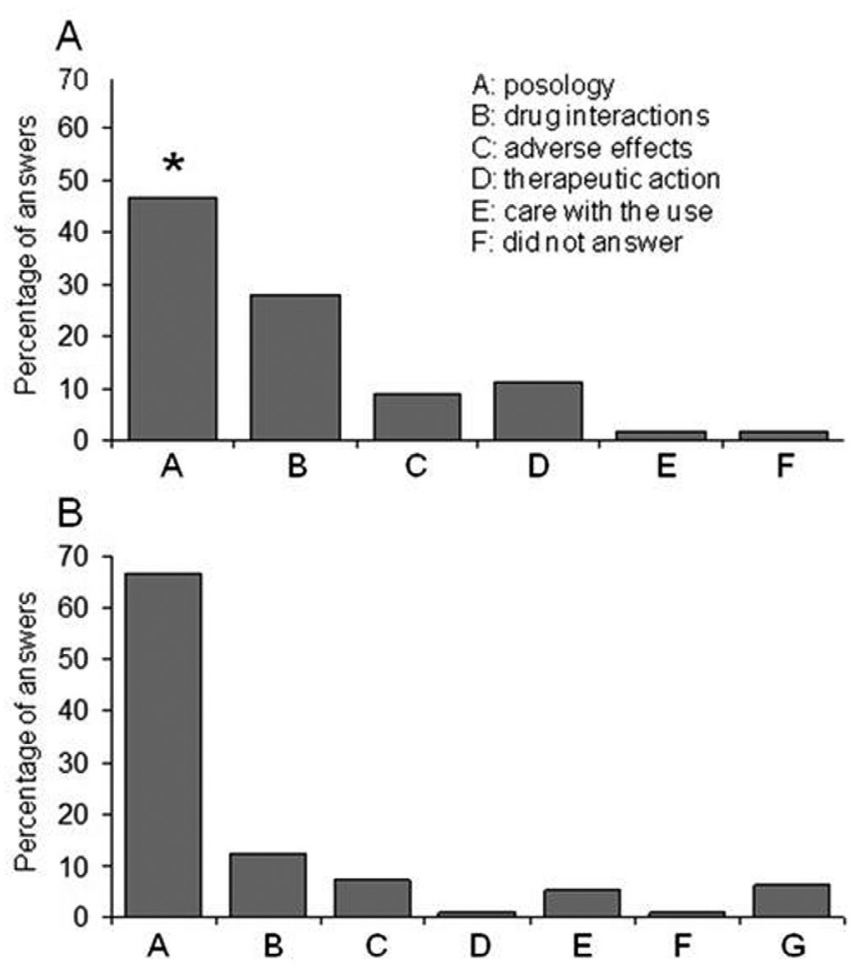

FIGURE 1 - Differences in the profile of patient doubts and guidance provided by pharmacists during the dispensation of antibiotics in Tubarão, Santa Catarina. Panel A: Doubts most frequently expressed by users in relation to antibiotics. Panel B: Guidance provided by the pharmacist at time of sale.

\section{DISCUSSION}

This is the first study, to the best of our knowledge, to demonstrate the profile of antibiotics dispensation in Tubarão, Santa Catarina. This expands the findings of another study conducted in 2001 by pharmacy students of the University of Southern Santa Catarina in the same municipality, which showed that the three antibiotics most frequently sold in the dispensing pharmacies of the area were amoxicillin, cephalexin and the combination of sulfamethoxazole with trimetropine (Martins, Martins, 2001).

Although this study has the limitation of relying on data reported by the respondents, which may generate some degree of uncertainty, it provides external validity for the results, based on sample size calculation and the number of respondents, i.e., all pharmaceutical establishments in operation in the municipality, except for prescription pharmacies, were interviewed. Moreover, these results are similar to those of another study that also evaluated the main clinical indications for the use of antimicrobials in Pelotas, Rio Grande do Sul, which were intended mainly for respiratory and urinary tract infections (Berquó, et al., 2004).
The large number of interviewees who reported dispensing antibiotics without medical prescription is of particular concern. Although the use of antibiotics often appears not to be for use in special groups, such as pregnant women, children and the elderly, it was found that this practice, i.e., selling without medical prescription, occurs more frequently in the treatment of throat and ear infections, sinusitis (upper respiratory tract infections), and urinary infections (Table I).

According to several authors (Stein, et al., 2004; Nascimento-Carvalho, 2006), this practice should be addressed, since the majority of acute respiratory infections are of viral etiology and therefore do not benefit from the use of antibiotics. According to the authors, these drugs provide only slight benefits for acute otitis media in children yet can significantly increase the occurrence of adverse effects associated with their use. Furthermore, with regard to cystitis, (the most prevalent urinary infection), the authors advise that risk factors for complications such as diabetes, pregnancy and persistence of symptoms for more than fourteen days must be investigated and patients referred to a physician to improve diagnosis through qualitative examination of urine and urine culture (AEPap, 2006).

With regard to criteria adopted by the interviewees concerning the sale of antibiotics without medical prescription, responses were recorded regarding pharmacists' concerns of allergies to medicines, as well as the severity of the symptoms and pathology. Although some of the above criteria are in agreement with several authors (AEPap, 2006), it should be noted that often, symptomatic treatment not directed to the cause can generate a worse prognosis. On drug interactions, some interviewee responses were supported by the literature, while others deserve more attention because they are clinically relevant (Table III). If the findings of the aforementioned study on the antibiotics most frequently sold in the area (Martins, Martins, 2001) are taken into account, caution must be taken with the interaction between cephalosporin and ethanol, which can provoke a reaction similar to that caused by disulfiram, manifested by tachycardia, bronchial spasm, sweating, and nausea, among other effects. Furthermore, the interaction of sulfonamides with hydantoines (such as phenytoin) may generate an increase in serum levels of the latter (Tatro, 2003).

Concerning recommendations at the time of antibiotics sales, it was observed that the percentage of pharmacists stating they provide guidance related to antibiotics posology was higher than the number of responses stating that users inquire about posology. This may reflect this class of professionals' concern over the effectiveness of 
TABLE III - Possible drug interactions of the different classes of antibiotics with other substances. Panel A: interactions classified as probable or possible by the literature consulted. Panel B: interactions classified as established by the literature consulted

\begin{tabular}{|c|c|c|c|}
\hline \multirow[t]{2}{*}{ A - Class of antibiotic } & \multicolumn{2}{|c|}{ Type of drug interaction } & \multirow[t]{2}{*}{ Observed effects in co-administration } \\
\hline & Probable & Possible & \\
\hline Penicillin & Not registered & Not registered & - \\
\hline Cephalosporin & Not registered & Not registered & - \\
\hline Aminoglycoside & Not registered & Not registered & - \\
\hline Lincosamide & Not registered & Not registered & \\
\hline Tetracycline & Not registered & Not registered & - \\
\hline \multirow[t]{5}{*}{ Chloramphenicol } & Not registered & Not registered & - \\
\hline & Carbamazepine & - & $\begin{array}{l}\text { Increasing concentration/toxicity of } \\
\text { carbamazepine } \\
\text { (except azithromycin) }\end{array}$ \\
\hline & - & Corticosteroid & $\begin{array}{l}\text { Increase in the pharmacological and toxic } \\
\text { effects of methylprednisolone }\end{array}$ \\
\hline & - & Cyclosporine & $\begin{array}{l}\text { Increase in toxicity of cyclosporine, } \\
\text { especially nephrotoxicity }\end{array}$ \\
\hline & - & Theophylline & $\begin{array}{l}\text { Increase in serum levels/toxicity of } \\
\text { theophylline, decreased serum levels of } \\
\text { erythromycin }\end{array}$ \\
\hline $\begin{array}{l}\text { Vancomycin, bacitracin and } \\
\text { polymyxin B }\end{array}$ & Not registered & Not registered & - \\
\hline Sulfonamides & Anticoagulants & - & $\begin{array}{l}\text { Increase of the anticoagulant effect of } \\
\text { warfarin, resulting in bleeding }\end{array}$ \\
\hline Quinolones & - & Theophylline & $\begin{array}{l}\text { Increase in serum levels/toxicity of } \\
\text { theophylline }\end{array}$ \\
\hline Metronidazole & Anticoagulants & - & $\begin{array}{l}\text { Increase of the anticoagulant effect of } \\
\text { warfarin, resulting in bleeding }\end{array}$ \\
\hline B - Class of antibiotics & \multicolumn{3}{|c|}{ Drug interaction established } \\
\hline Penicillin & \multicolumn{3}{|l|}{-} \\
\hline Cephalosporin & \multicolumn{3}{|l|}{ Ethanol } \\
\hline Aminoglycoside & \multicolumn{3}{|c|}{ Loop diuretics, non-depolarizing muscle relaxants } \\
\hline Lincosamide & \multicolumn{3}{|l|}{-} \\
\hline Tetracycline & \multicolumn{3}{|c|}{ Salt or food containing calcium, magnesium or iron salts } \\
\hline Chloramphenicol & \multicolumn{3}{|l|}{-} \\
\hline Macrolide & \multicolumn{3}{|c|}{ Anti-histamines, cisapride, anticoagulants, digoxin, simvastatin, lovastatin } \\
\hline $\begin{array}{l}\text { Vancomycin, bacitracin and } \\
\text { polymyxin B }\end{array}$ & \multicolumn{3}{|c|}{ Non-depolarizing muscle relaxants } \\
\hline Sulfonamides & \multicolumn{3}{|l|}{ Hydantoin } \\
\hline Quinolones & \multirow{2}{*}{\multicolumn{3}{|c|}{ Antacids, salts containing iron }} \\
\hline Metronidazole & & & \\
\hline
\end{tabular}

Drug interactions with grades 1 and 2 of clinical significance were selected for analysis, according to the reference literature consulted (Tatro, 2003).

treatment, which is only achieved by administering the drug over a period of time for each agent. These data are in agreement with the results obtained by other authors. For instance, Nicolini, et al., 2008 demonstrated in a study of public pharmacies in the state of São Paulo, that up to $10.7 \%$ of patients treated with antibiotics did not know about their diagnosis, while $15.4 \%$ did not understand the posology. According to these authors, the population over
50 years of age needs the most help in understanding their diagnosis and prescribed posology. In our opinion, this fact deserves the pharmacists' attention, as the practices of guidance and population education are an important part of their field of expertise. This idea is reinforced in other studies, which consider the promotion of health and the rational use of medicines to be a major contribution of pharmacists to the community (Vieira, 2007). 
Another significant finding is the fact that, at the time of the visit by the interviewers, nearly 30 percent of the establishments had no pharmacist on duty. This finding, taken together with those previously discussed, reinforces the need for adoption of measures by the respective regulatory bodies. These measures may include expansion of sanitary vigilance and, regarding the technical-scientific issues of the interviewees, the review of undergraduate curriculum, as well as the provision of continuous training courses to address the problems exposed.

In conclusion, this study showed a high frequency of antibiotics sales without medical prescription (mainly for diseases of the respiratory and urinary tract), while demonstrating pharmacists' concerns in stressing, at the time of dispensation, guidelines on posology and possible drug interactions of this class of medicines. It should be emphasized that these professionals should follow the guidelines set forth by official and regulatory bodies, together with other professional entities, especially in campaigns for population education to reduce the unnecessary use of antibiotics and assure that they are dispensed only under medical prescription.

\section{REFERENCES}

\section{ASOCIACIÓN ESPAÑOLA PEDIATRÍA DE ATENCIÓN} PRIMARIA. Documento de consenso sobre la utilización de antibióticos en atención primaria. Madrid, 2006. 10 p.

BERQUÓ, L. S.; BARROS, A. J. D.; LIMA, R. C.; BERT, A. D. Utilização de antimicrobianos em uma população urbana. Rev. Saúde Pública, v.38, p.239-246, 2004.

HOWARD, D. H.; SCOTT, R. D.; PACKARD, R.; JONES, D. The global impact of drug resistance. C.I.D., v.36, p.S4-S10, 2003.

LUCHESSI, A. D.; MARÇAL, B. F.; DE ARAÚJO, G. F.; ULIANA, L. Z.; ROCHA, M. R. G.; PINTO, T. J. A. Monitoração de propaganda e publicidade de medicamentos: âmbito de São Paulo. Rev.Bras. Ciênc. Farm., v.41, p.345-349, 2005.
MARTINS, M. S.; MARTINS, L. P. Desenvolvimento de um material informativo sobre os antibióticos mais vendidos nas farmácias de dispensação de Tubarão-S.C. Tubarão, 2001. 50f. [Trabalho de Conclusão de Curso. Curso de Farmácia. Universidade do Sul de Santa Catarina].

NASCIMENTO-CARVALHO, C. M. Antibioticoterapia ambulatorial como fator de indução da resistência bacteriana: uma abordagem racional para as infecções de vias aéreas. J. Pediatr., v.82, p.S146-S152, 2006.

NICOLINI, P.; NASCIMENTO, J. W. L.; GRECO, K. V.; DE MENEZES, F. G. Fatores relacionados à prescrição médica de antibióticos em farmácia pública da região Oeste da cidade de São Paulo. Cienc. Saúde Coletiva, v.13, p.689696, 2008.

OLIVEIRA, A. O. T.; PEDROSO, C. F.; MIGUEL, M. D.; MONTRUCCHIO, D. P.; ZANIN, S. M. W.; DORNELES, D. Atenção farmacêutica na antibioticoterapia. Visão Acad., v.5, p.7-14, 2004.

ORGANIZAÇÃO MUNDIAL DA SAÚDE. O papel do farmacêutico no sistema de atenção à saúde. Brasília, 2004. 92p.

STEIN, A.; BEHAR, P.; CUNHA, C. R.; PELLEGRIN, L.; FERREIRA, J. A. S. Uso racional de antibióticos para médicos de atenção primária. AMRIGS, v.2, p.126-134, 2004.

TATRO, D.S. Drug interaction facts. Missouri: Lippincott Williams \& Wilkins, 2003. 1424 p.

VIEIRA, F. S. Possibilidades de contribuição do farmacêutico para a promoção da saúde. Cienc. Saúde Coletiva, v.12, p.213-220, 2007.

WORLD HEALTH ORGANIZATION. Global strategy for containment of antimicrobial resistance. Geneva, 2001. $105 \mathrm{p}$.

Received for publication on 22th October 2008. Accepted for publication on 19th May 2009. 
